\title{
SOVIET PASSPORTS AND THEIR IMPLEMENTATION IN EAST AND SOUTHEAST LITHUANIA (1944-1989)
}

\author{
Vitalija Stravinskiene
}

(Lithuanian Institute of History)

\begin{abstract}
There was one very special document in the life of each adult citizen of the USSR. This document was the internal passport, which was a short chronicle of a person's life. It reflected almost the whole life of an individual: from the place and time of their birth, to the duties the holder had to their children (indicated by a stamp in the passport about any underage children and any duty the parent had to support them financially). This article presents an analysis of the development of the Soviet passport system in east and southeast Lithuania in the period 1944 to 1989, and efforts to introduce modernisation, revealing the functions and some details of the universal obligatory registration of citizens based on their place of residence.
\end{abstract}

KEYWORDS: passports; registration of citizens; east and southeast Lithuania; 'passport regime area'; pasportisation.

\section{Introduction}

The Soviet government attempted to implement total control over the life of the individual. Probably the most effective way of controlling a person was a small-format book, the Soviet passport, without which a person could not be employed, study, start a family, or change their place of residence. We can agree with the researcher Albert Baiburin that the Soviet passport was not simply a document testifying to a person's identity: it was a unique document of documents, which was usually more important than the actual person whose existence it attested to. ${ }^{1}$

${ }^{1}$ А. Байбурин, 'К предысловии советского паспорта (1917-1932)', Henpeкосновенный запас, 2(64) (2009), http://magazines.russ.ru/nz/2009/2/ba8.html (accessed: 2019-01-12). 
The passport system in the USSR has been analysed as an effective means of control of population movements and society on the whole, and also as a way of resolving ethnic issues. ${ }^{2}$ However, these studies concentrated mostly on a general all-union state level, usually highlighting the situation in Russia. Only on a few occasions has attention focused on how this system functioned in separate Soviet republics or regions. ${ }^{3}$

The Soviet passport system in Lithuania is only starting to be researched. Until now, only one article on this issue, by the historian Regina Laukaitytè, has been published. ${ }^{4}$ She analysed the functioning of the Soviet passport system in Lithuania during the Stalinist period (1944-1953). The author distinguishes two rounds of the issue of Soviet passports (in 1944-1946, and in 1953), and

${ }^{2}$ M. Matthews, Passports and Residence Controls in the Soviet Union, 1991, https://www.ucis.pitt.edu/nceeer/1991-804-05-Matthews.pdf (accessed: 2019-01-12); G. Kessler, 'The Pasport System and State Control over Population Flows in the Soviet Union, 1932-1940', Cahiers du monde russe, 42 (2001), pp. 477-504, https://pdfs. semanticscholar.org/1664/58c30595a477f7eeo8bac931e3oc6743b814.pdf (accessed: 2019-01-12); Режимные люди в СССР, отв. ред. Т. С. Кондратьева, А. К. Соколов (Москва, 2о09); А. Байбурин, Советский паспорт. История-структура-практики (Санкт-Петербург, 2017); Н. Муан, 'Паспортная система и выбор места жительства в Росии и Советском Союзе', Непрекосновенный запас, 4(42) (2005), http://magazines.russ.ru/nz/2005/42/mug.html (accessed: 2019-01-12); В. Попов, 'Паспортная система советского крепосничества', Новый мир, 6, (1996), http://magazines.russ.ru/novyi_mi/1996/6/popov-pr.html (accessed: 2019-о1-18); К. Любарский, 'Паспортная система и система прописки в СССР', Российский бюллетень по правам человека, 2 (1994), pp. 14-24, http://www.demoscope.ru/weekly/2002/o93/ arxivo1.php (accessed: 2019-01-20); Y. Kirichenko, 'Historic and Legal Review on Passport Reform of 1974 and its Role in Strengthening of the USSR Public Order', Bylye Gody, 34, 2014, (2014), pp. 707-713, http://oaji.net/articles/2015/7-1426237552. pdf (accessed: 2019-01-18).

${ }^{3}$ I. Paavle, 'The Evolution, Regulation and Implementation of the Soviet Internal Passport System in the Estonian SSR, Part I', Tuna, 2 (2010), pp. 37-53, http://www. mnemosyne.ee/old/wp-content/uploads/2011/o5/Indrek_Paavle_-_Passport_System. pdf (accessed: 2019-01-12); I. Paavle, 'The Evolution, Regulation and Implementation of the Soviet Internal Passport System in the Estonian SSR, Part II', Tuna, 2 (2011), pp. 43-67, http://www.mnemosyne.ee/old/wp-content/uploads/2011/o6/ Indrek_Paavle_-_Passport_System_II.pdf (accessed: 2019-01-12); E. Chernoludskaya, 'Паспортизация Дальневосточного населения (1933-1934)', Revue des Études Slaves, 71/1 (1999), pp.17-33, https://www.persee.fr/doc/slave_oo8o-2557_1999_num_71_1_6575 (accessed: 2019-02-25).

${ }^{4}$ R. Laukaitytė, 'Sovietinio pasų režimo įvedimas Lietuvos SSR 1944-1953 metais', Teise, 107 (2018), pp. 51-65. 
discusses the mechanism behind implementation and the efforts of certain citizens to override the system (the existence of fake passports, and living without obligatory registration). However, the case of east and southeast Lithuania has not been researched, only being discussed in the general context of the republic.

Papers by Arūnė Liucija Arbušauskaitė and Vasilijus Safronovas mention the issue of Soviet passports to the population in the Klaipeda region. ${ }^{5}$ In this region, due to the military activity during the Second World War, the issue of Soviet passports commenced later than in the east of the country.

A monograph by the lawyer Vytautas Sinkevičius is also worth mentioning, as the author looks into legal aspects of citizenship of the Republic of Lithuania, and yet also reviews the circumstances under which Soviet citizenship was granted. ${ }^{6}$ According to him, Soviet citizenship was forced on all residents in the republic from the beginning of the Soviet occupation (3 August 1940). ${ }^{7}$ This situation remained until the end of 1989 .

The above research is enriched by document anthologies, ${ }^{8}$ press publications ${ }^{9}$ and the memories and impressions of witnesses from those times ${ }^{10}$ about the circumstances regarding citizen registration and the issue of passports.

Primary archive material in Lietuvos ypatingasis archyvas (Lithuanian Special Archives; LYA) and Lietuvos centrinis valstybės archyvas (Lithuanian Central State Archives; LCVA) forms

${ }^{5}$ A.L. Arbušauskaitė, 'Tapatumo sūpuoklèse tarp pilietybės ir tautybės: Klaipėdos krašto gyventojai XX amžiuje', Acta Historica Universitatis Klaipedensis, XXIII (2011), pp. 171-172; V. Safronovas, Migrantai ir pabėgèliai Kuršiu nerijoje XX amžiaus viduryje (Vilnius, 2018), p. 67.

${ }^{6}$ V. Sinkevičius, Lietuvos Respublikos pilietybe 1918-2001 metais (Vilnius, 2002), pp. $85^{-126 .}$

${ }^{7}$ Ibid., p. 90.

${ }^{8} \mathrm{~V}$. Tininis, Komunistinio režimo įtvirtinimas Lietuvoje ir jo nusikaltimai. Antroji sovietiné okupacija (1944-1953) (Vilnius, 2009); Pasu nuostatams taikyti Instrukcija ([s. n.] [1940]); Normatyviniu aktu rinkinys milicijos darbuotojui. Tarnybiniam naudojimui, sud. J. Vižinis, V. Šulus, Vilnius, 1971.

${ }^{9}$ Journals: Советская Литва; Milicijos darbuotojas, Liaudies sargyboje.

${ }^{10}$ I. Liutkevičienė, Déjà vu. Vilnius 1974-199o (Vilnius, 2012); I. Jakinevičiūtè, Pasu itteikimo vakaras - jaunuju piliečiu šventè (Vilnius, 1964); M. Römer, Dzienniki, t. 6: 1939-1945, oprac. J. Sienkiewicz (Warszawa, 2018). 
the main basis of information for this article. The first archive holds documents of Soviet structures that controlled the lives of Lithuanian society (from Communist Party committees, the People's Commissariats for Internal Affairs and State Security, and later from ministries and their departments): various resolutions, announcements, reports, correspondence with leaders in Moscow and institutions in Lithuania, etc. The collections in the Ministry of Internal Affairs Archive Division (V-102, V-105) and the Communist Party of Lithuania (CPL) document store (col. 1771, 3404) are especially noteworthy. This material helped reconstruct the Soviet passport process, to reveal its dynamics and the results achieved, and the efforts to modernise the passport system.

The collections in the LCVA and Vilniaus regioninis valstybès archyvas (Vilnius Regional State Archives; VRSA) (R-754, R-786, $\mathrm{R}-363,761$, etc) were useful for analysing the Soviet passport system's implementation mechanism from a horizontal aspect, its legal foundations, and the attempts by Party and administrative government bodies to control the movement of the population and to determine the shortcomings of universal obligatory registration, etc. In order to reconstruct how Soviet passports and population movement control functioned, data had to be selected from this enormous body of documents, as a great number of institutions and branches were involved in these processes.

In order to examine whether there were any special features in east and southeast Lithuania in the postwar years in the implementation of the Soviet passport system, documents from LSSR and Polish evacuation institutions from this time were used. They are kept in the LCVA and Archiwum Akt Nowych (Polish Central Archives of Modern Records; AAN in Warsaw. They show that people from this region who had to go to Poland did not need to be issued with Soviet identity documents. However, in reality, the situation was different: most Poles living in Vilnius received Soviet passports. In order to correct the situation, the Soviet government ordered a campaign to re-register the documents, and to take back Soviet passports issued to the city's inhabitants, forcing their former holders to move to the new geographic space that emerged in Poland. 
The aim of this article is to analyse the introduction of the Soviet passport system in a regional context (east and southeast Lithuania), and to explain how the implementation of the Soviet passport system proceeded and how it was improved during Soviet times, the significance of the universal obligatory registration of citizens and how it functioned, and how it was controlled.

\section{The implementation and modernisation of the Soviet passport system: 1944-1989}

In order to understand how the Soviet passport system functioned after 1944, it is necessary to discuss at least briefly its implementation during the first Soviet occupation. Generally speaking, the work that commenced at the start of the war was to be continued at the end of the Second World War. According to the decree of the Presidium of the Supreme Soviet of the USSR of 7 September 1940 'On Procedures for Receiving Citizenship of the USSR for Citizens of the Lithuanian, Latvian and Estonian Soviet Socialist Republics', residents of the LSSR became citizens of the USSR from the day the republic was incorporated into the USSR, i.e., 3 August 1940. ${ }^{11}$ Not only did everyone who was in the LSSR at the time become Soviet citizens, but so did people who were born in the republic who found themselves beyond its borders.

In the autumn of 1940, in implementing resolution No 1667 of the Council of People's Commissars (CPC) of the USSR, preparations began to introduce the Soviet passport system in Lithuania. ${ }^{12}$ Passports would be issued to people in cities and border zones (the Marijampolé, Šakiai, and other similar districts), and people living in Machine-tractor Stations (MTS) and collective farms. It was calculated that 534,100 passports were to be issued in $1941 .{ }^{13}$ In the case of east and southeast Lithuania, 180,6 oo people over the age of 16 were to be issued with passports, of whom 167,800 were residents of Vilnius. ${ }^{14}$

${ }^{11}$ V. Sinkevičius, Lietuvos Respublikos..., pp. 87, 90.

${ }^{12}$ Pasu nuostatams taikyti Instrukcija, p. 1.

${ }^{13}$ LSSR NKVD Militsiya Board Passport Registration Branch deputy chairman's project for the issue of passports to citizens of the LSSR, 21 April 1941, Lithuanian Central State Archives (LCVA), col. R-786, inv. 5, file 33, p. 9.

${ }^{14}$ Ibid., pp. 4-5. 
Before implementing the passport campaign, cadres who would actually be able to issue the passports had to be found. They were to be assembled from the staff of other divisions. Between 1 April and 1 September 1941, various agencies had to select and provide staff, who knew Russian and Lithuanian, for the new teams being formed under the Ministry of Internal Affairs. ${ }^{15}$ Judging by the period of these teams, the issue of passports was to be implemented over these few months. The LSSR Party leadership indicated that the process had to be forced, and the residents of Vilnius would be the first group to be processed. ${ }^{16}$ However, the reality proved to be more complicated. On 28 May 1941, it was noted at a meeting of the Bureau of the Central Committee of the Lithuanian Communist Party (CPL CC) that the issue of Soviet passports was proceeding in a particularly unsatisfactory fashion. ${ }^{17}$ Of the 54,300 adults who should have received passports from 15 to 20 May, only 20 per cent $(9,900)$ were actually issued with the document. ${ }^{18}$ Plans were put in place to accelerate the campaign. However, the outbreak of war between the USSR and Germany disrupted these and other plans.

Soon after the Soviet reoccupation of Lithuania, the issue of passports was raised again. Sixty-three special Soviet document (passport) issue offices were opened in Soviet-occupied Lithuania in the autumn of 1944, as a way of continuing with preparations for the universal issue of passports. ${ }^{19}$

During the period discussed, two stages in the Soviet passport system can be distinguished: 1) the reinstatement of the Soviet passport system in 1944-1953; and 2) the modernisation of the passport system in 1953-1989. The threshold year was 1953, when the USSR government initiated changes to the passport and citizen registration system. These changes were expressed as a reduction

${ }^{15}$ Communist Party of Lithuania Central Committee (CPL CC) Bureau meeting protocol No 5, 22 February 1941, Lithuanian Special Archives (LYA), col. 1771, inv. 2, file 64, p. 5 .

\footnotetext{
${ }^{16}$ CPL CC Bureau meeting protocol No 9, 19 March 1941, ibid., inv. 2, file 76, p. 5 .

${ }^{17}$ CPL CC Bureau meeting protocol No 24, 28 May 1941, ibid., file 121, p. 8.

${ }^{18}$ Ibid.

${ }^{19}$ R. Laukaitytė, 'Sovietinio pasų režimo...', p. 53.
} 
in the number of 'passport regime areas' ${ }^{20}$ and the minimisation of the restricted access border zone. ${ }^{21}$ In reality, this meant a better chance for those persecuted by the Soviet regime (former political prisoners and deportees) to settle in cities or towns that had been removed from the list of 'passport regime areas'. This more liberal situation was determined by the release of thousands of political prisoners and deportees from labour camps as part of the de-Stalinisation process following Stalin's death. In order to solve the associated social problems, certain changes were introduced in population movement and registration. In the case of east and southeast Lithuania, no significant changes occurred, for the most attractive place where citizens wished to reside, the republic's capital, Vilnius, was still a first-category 'passport regime area'. Former political prisoners or deportees were not wanted there. And yet 1953 did bring about certain changes for the residents of Lithuanian villages. Instead of temporary ID certificates, they were now eligible for passports.

Another important question in this research is just how many Soviet passport campaigns occurred between 1944 and 1989? The historian R. Laukaityte has distinguished the following: 1) 1944-1946, when all citizens of the republic older than 16 were issued with Soviet ID documents; 2) the spring of 1953, when people living in rural areas received new temporary ID certificates, valid for three years, and the end of the year when they were issued with new, fixed-term (five and ten-year) and not fixed-term passports. ${ }^{22}$ As the author mentions, the Soviet passport system was modernised in the second half of the 1970s. Thus, a third passport campaign can also be distinguished: 1976 to 1981 , when passports were issued to all adult citizens of the Soviet state. This was especially important to rural populations in Russia, Belarus, and other regions who did not have passports at all. As citizens of Lithuania aged

${ }^{20}$ A 'passport regime area' was a place where citizens had to have passports, and had to be registered; anyone with a special entry in their passports (about convictions) could not live in these areas (they would not be registered, and would be ordered to leave).

${ }^{21}$ R. Laukaitytè, 'Sovietinio pasų režimo...', p. 6o.

${ }^{22}$ Ibid., p. 53; M. Matthews, Passports and..., p. 5 . 
over 16 already had passports, for them, this campaign just meant that they had to get the new type of Soviet passport, of which $2,673,8$ oo were issued. ${ }^{23}$

The implementation and modernisation of the Soviet passport system was regulated by resolutions passed along a vertical principle, i.e., analogous resolutions were passed at the republic level once the initial resolution was passed by the Central Committee of the Communist Party of the USSR and the Council of Ministers. Their practical realisation was controlled in accordance with the same principle, in the form of decrees, instructions, directives, etc, passed down from Moscow to Vilnius, Riga or Minsk by central internal and security structures. The situation of individual locations and their population also depended on the decisions made by the republic's institutions, which either liberalised, or conversely, restricted matters. A resolution by the LSSR Council of Ministers in 1957 restricted citizens being registered in Vilnius, and yet in 1966 the LSSR minister of higher and secondary special education liberalised the situation for a certain group of students, allowing them to be registered unde'r the higher education institution they attended (there is more on this in the subsection on the universal registration of citizens).

As Laukaityte mentions, during the Stalinist years, the passport provided a great deal of information about its owner: apart from personal data (name, surname, place and date of birth, etc), there was also information about their social and ethnic situation (social origin, nationality, family members, spouse's name and surname, date of marriage, convictions, and place of work), and any duties related to the state (military service history), etc. ${ }^{24}$ After the reform of the passport system in the 1970s, some information no longer had to appear in the new passports: social origin and place of work. ${ }^{25}$ In addition, unlike the earlier passports, the new personal document did not have a fixed term. Whereas after the

${ }^{23}$ Announcement by the LSSR Ministry of Internal Affairs Passport Branch chairman P. Semènas at a meeting of the LSSR Ministry of Internal Affairs Militsiya Board primary party organisation, 22 February 1979, LYA, col. 3404, inv. 2, file 312, p. 14.

${ }^{24}$ R. Laukaitytè, 'Sovietinio pasų režimo...', p. 58.

${ }^{25}$ Y. Kirichenko, 'Historic and Legal...', p. 708. 
end of the five or ten-year validity of the earlier passports, a new one would have to be issued when the holder turned 25 and 45 , a new photograph would simply need to be stuck into the same passport. However, some innovations were also introduced. People who had been convicted for evading providing material support to their children, that is, those who intentionally avoided paying alimony, had a special stamp referring to this in their passports, and their surnames would appear on special registers at the local branch of the militsiya.

Another campaign seeking to modernise Soviet citizenship took place in Lithuania in 1989, when the country was moving towards restoring its statehood. A new law on LSSR citizenship was passed, according to which citizens of the republic were those who had been citizens since 3 August 1940, and their descendants, as well as people who had lived and worked there constantly, and who expressed the desire to become citizens of the LSSR. ${ }^{26}$ The law basically repeated the former provisions in legal acts that regulated Soviet citizenship (citizens of the LSSR included everyone who lived in the republic at the time), but it did put in place conditions for the residents of Lithuania to participate in restoring the country's independence. ${ }^{27}$

Having to change passports in relation to changing one's nationality can also be viewed as an expression of liberalisation at this time. This phenomenon was observed in 1988-1989, when some people went from being considered Belarusians to Poles. ${ }^{28}$ People who had moved from Belarus to Vilnius during the Soviet years made up the majority of this group who wished to change their nationality. However, there is no data about the total number of such people in Lithuania, and this question would demand separate research.

${ }^{26}$ V. Sinkevičius, Lietuvos Respublikos..., p. 124.

${ }^{27}$ For more about the relationship between citizenship of the LSSR and the Republic of Lithuania in 199o, see: V. Sinkevičius, Lietuvos Respublikos..., pp. 118-126; B. Kunigèlytė-Žiūkienė, Valstybiu teisiu perémimas, neteisèti teritoriniai pokyčiai ir pilietybè. Doctoral dissertation (Vilnius, 2015), pp. 55-56.

${ }^{28}$ Resolutions of various Vilnius City Passport Branch chairmen in 1988-1989, LYA, col. L-4/46, inv. 1, file 133-134. 


\section{The situation in Vilnius and the surrounding area}

Due to the plans implemented by the USSR aimed at homogenising the state's western peripheries, a special situation existed in east and southeast Lithuania (the situation was different in the Vilnius region). The Soviet government intended to move Polish residents, who made up the majority in this region (and also in western Ukraine and western Belarus), to Poland, and in turn expected Lithuanians to return from Poland to Lithuania. A special campaign was organised for this purpose, which took place in 1944-1947. Jumping ahead of these events, the results of the campaign were astonishing: of the approximately 500,000 inhabitants of Vilnius and the surrounding area, around 361,0oo signed up to 'become' Poles, with 169 , 000 actually departing. ${ }^{29}$ Around 50 per cent of those who moved were former residents of Vilnius. On the other hand, this region stood out from other regions in the republic, as it included Vilnius, the capital. Therefore, the attention that government institutions put on Vilnius was greater, and likewise, control of its citizens was also stricter. In the case of the Vilnius region, the situation was somewhat different, as its geographical location and historical links (it bordered neighbouring Soviet Belarus, from which migration towards Vilnius had set in much earlier on) drew people from the neighbouring republic, for it was seen as a better starting position. Once someone settled there and put their passport in order (they would receive a Soviet passport, for residents of Belarusian villages were not eligible for one until 1976), they would try to move to live in the Lithuanian capital, or in other regional cities.

With the agreement of the LSSR Militsiya Board and Stanisław Ochocki, the senior authority on evacuation to Poland, it was decided that Poles who had signed up to leave for Poland would not be issued with passports. ${ }^{30}$ However, the actual situation was

${ }^{29}$ N. Kairiūkštytè, 'Vilniaus krašto gyventojų sudèties pokyčiai 1939-1946 m.', Lietuvos Rytai, sud. K. Garšva, L. Grumadiene (Vilnius, 1993), pp. 288-289, 291-292; V. Stravinskienè, Tarp gimtinès ir Tèvynès: Lietuvos SSR gyventoju repatriacija į Lenkiją (1944-1947, 1955-1959 m.) (Vilnius, 2011), pp. 165, 175.

${ }^{30}$ Note from S. Ochocki, the Polish National Liberation Committee's senior authority for relocation from the territory of the LSSR, to the State Repatriation 
different. At the end of 1944 and in early 1945, with passports being issued in Vilnius, most Polish residents of the capital managed to secure passports, and demonstrated that they were in no hurry to sign up to leave for Poland. One witness to these events wrote:

'When they started issuing passports there [on Totoriu St], at least for our street, from the very beginning, there was an enormous queue to submit documents to receive a passport; they would sometimes spend all day in the queue, and come away with nothing, so they would have to return the next day and start all over again. Passports would be issued at 5 or 6 o'clock in the evening to those who had submitted their documents during the day. There were queues again.... ${ }^{1}$

People's reasons for wanting a passport were understandable: it was impossible to be employed without a passport, and without employment it was impossible to receive cards for food or household goods. Without them, life in the city was incredibly difficult. This closed loop forced people to try to get Soviet documents. However, the situation did not satisfy Moscow's representatives in Lithuania. In early 1945, at a meeting of the CPL (Bolshevik) Central Committee Bureau, the matter of Polish resettlement was discussed, and it was stated that militsiya staff had not dealt with the issue of passports in a satisfactory way, that passports had been issued to most of those who had applied for them, and that (too) many people of Polish nationality had been involved in this work. According to the participants in the meeting, the resulting situation was dangerous, and put the resettlement of Poles at risk altogether. The LSSR people's commissar for internal affairs was ordered to make the issue of passports stricter, to see that passports were not issued to the unemployed and those who did not have the proper documents, and to take the necessary measures for taking back passports from those people who had been issued them wrongly, ${ }^{22}$ i.e., from people who had signed up to leave and resettle in Poland. Passport re-registration followed as a way of carrying out this order. It took place between 5 February

Office, 30 December 1944, Polish Central Archives of Modern Records (AAN), col. 522, file 29, pp. 2-3.

${ }^{31}$ M. Römer, Dzienniki, pp. 628-629.

${ }^{32}$ Meeting protocol of the CPL (Bolshevik) CC, 24 January, V. Stravinskienė, Tarp gimtinés..., pp. 396-397. 
and 15 March $1945 \cdot{ }^{33}$ This time, people of Polish nationality were removed from positions where they could see to the registration and issue of passports, and a special sticker would be stuck to the 'right' passports. It is worth noting that this campaign aimed to 'pressure' Poles living in the city to register to resettle in Poland. People falling into this category were told: 'Passports shall not be re-registered for those who expressed the desire to leave for Poland, they should be presented to branches of the militsiya based on residential address. ${ }^{34}$ People who had signed up to resettle in Poland could only stay in Vilnius until their set day of departure. The results of this passport re-registration met the Soviet government's expectations. During the first round, residents of Vilnius were issued with 63,6oo personal ID documents; during the re-registration campaign, as of 25 July 1945, only 23,500 people were allowed to keep their documents. ${ }^{35}$ Readers should be reminded that the issues of Soviet passports and registration for resettlement in Poland took place at the same time. People could express their wish to move to the neighbouring country for around two months, i.e., from 28 December 1944 until March 1945. ${ }^{36}$

Passports were issued simultaneously in Kaunas and another 18 towns. ${ }^{37}$ At the start of 1945 , the residents of some towns in the Vilnius region (Naujoji Vilnia, Švenčionys, etc) were also issued with passports (series TЭ). Even though this has not been

33 Order from the LSSR people's commissar for internal affairs Bartašiūnas, 29 January 1945; Resolution No 39-s of the LSSR Council of People's Commissars, 30 January 1945, LYA, col. V-102, inv. 1, file 1, p. 105, 100.

34 'Перерегистрация паспортов', Советская Литва, о3 о2 1945, p. 4.

35 Top secret report to the USSR People's Commissariat for Internal Affairs chairman of the Supreme Militsiya Board, Galkin, about the work done in issuing passports in the territory of the LSSR, LYA, col. V-102, inv. 1, file 1, p. 14; report from the LSSR State Security Deputy People's Commissar Yefimov and chairman of the 2nd Branch Pochkay to the USSR State Security People's Commissariat and Board chairman Fedotov, 23 July 1945, ibid., col. K-1, inv. 10, file 22, p. 297.

${ }^{36}$ News about the number of people wishing to relocate to Poland, 26 March 1945, ibid., col. 1771, inv. 8, file 197, p. 15 o.

37 Top secret report from the USSR NKGB Supreme Militsiya Board Passport Branch deputy chairman Chizhikov about the work done to reinstate the passport system in the LSSR, ibid., V-102, inv. 1, file 1, p. 14. 
recorded in documents, we can presume that, similarly, residents who had been on the lists to resettle in Poland also had to return their Soviet passports.

The inhabitants of villages in the region were issued with passports in 1946. Fewer passports were required there than in other regions, due to the migration of Poles to Poland. A total of 93,8 oo passports were issued in the Vilnius, Trakai and Švenčionys districts. ${ }^{38}$ According to the Soviet government's calculations, these districts had a population of 325 , ooo in $1945 .{ }^{39}$

\section{The universal obligatory registration of citizens}

The citizen registration system was developed parallel with the implementation of the passport system. It came into effect in the USSR in 1922, with the aim of collecting information about migration and all the population. ${ }^{40}$ Based on the resolutions of the Council of People's Commissars of the LSSR, ${ }^{41}$ the mandatory registration of citizens in the republic started being carried out in the autumn of 1944, and continued until the end of the Soviet period. Incidentally, in later years, additional amendments were passed that either liberalised or further restricted the situation for certain members of the population. In the case analysed here, the resolution of leaders of the republic of 25 July $1957^{42}$ was significant, for it restricted the possibility to be registered in Vilnius. At that time, it resulted in the first negative mechanical growth (the ratio between arrivals and people who left the city)

${ }^{38}$ V. Tininis, Komunistinio režimo..., p. 396.

${ }^{39} \mathrm{~V}$. Stravinskienè, Tarp gimtinès..., pp. $47,5^{2-53}$.

${ }^{40}$ Г. Гура, 'Особенности паспортной системы Российской Федерации', Територия науки (2013), p. 163, https://cyberleninka.ru/article/v/osobennosti-pasportnoy-sistemy-rossiyskoy-federatsii (accessed: 2019-02-25).

${ }^{41}$ Resolution No 75 'On the Registration of Citizens in Locations Liberated from German Occupation', 12 August 1944, Resolution No 200-s 'On the Documentation and Registration of Citizens in the cities of Vilnius and Kaunas', 23 November 1944, Resolution 'On Document-Keeping and Registration in the Territory of the Lithuanian SSR', 12 December 1944, LCVA, col. R-754, inv. 1, file 15, p. 98; LYA, V-102, inv. 1, file 1 , pp. $27,42-46$.

${ }^{42}$ LSSR Council of Ministers Resolution No 359, 25 July 1957 'On Serious Shortcomings in the Registration of Citizens and Allocation of Living Space in Vilnius'. 
since the postwar years $(-3,500$ people $) .{ }^{43}$ This situation was due to registration restrictions and the renewed migration of Poles from the LSSR to the People's Republic of Poland. Similar registration restrictions were introduced in Vilnius in later years as well (as in the other major cities in Lithuania). By the end of the Soviet period, the registration of imprisoned or sentenced individuals in the capital was restricted. ${ }^{44}$

Nonetheless, there were some resolutions that actually liberalised registration in the capital for a certain segment of the population. Some of those worth mentioning are: 1) in 1963, in accordance with the resolution of the Vilnius City Executive Committee, people living in various communal apartments (belonging to educational institutions, enterprises or organisations) were allowed to be registered. This had hitherto been impossible, as they were not considered to have met the minimum living space requirement per person based on sanitary norms. ${ }^{45}$ This resolution was passed when major shortcomings in the population migration system became apparent in the republic (some people had not been de-registered from their old place of residence, nor had they been registered at their new address), and the LSSR Council of Ministers gave orders to fix this anomaly; ${ }^{46}$ 2) the order of the LSSR minister for higher and special secondary education dated 22 August 1966, which allowed all university students and special educational institution pupils who had not been able to register where they actually lived at the time (e.g., in a rented apartment), to register at their educational institution. ${ }^{47}$ The situation of these people (not only school and university students, but employees

43 V. Stravinskienė, 'Migracijos procesu poveikis Vilniaus miesto gyventoju etniniams demografiniams pokyčiams 1944-1959 metais', Lietuvos istorijos metraštis 2009/2, p. 146.

${ }^{44}$ Secret note of the LSSR internal affairs minister S. Lisauskas and the chairman of the Political Branch P. Buikas, March 1989, LYA, col. V-105, inv. 1, file 54, p. 114.

45 Results of mechanical migration in the LSSR in 1963, LCVA, col. R-363, inv. 1, file 6918 , p. 6 .

${ }^{46}$ Resolution No 474 of the LSSR Council of Ministers, 27 July 1962, ibid, col. R-754, inv. 1, file 634, pp. 1-3.

${ }^{47}$ Order No 307 from the LSSR minister of higher and special secondary education H. Zabulis, 22 August 1966, ibid., col. R-507, inv. 1, file 943, pp. 121-122. 
as well) was quite complicated. On checking the documents of those living at a specific residence, if government representatives found someone who was not registered at that address, the owner of the room would be fined, and would in turn have to order their subtenant to move out. ${ }^{48}$

A more significant change in the mandatory system of citizen registration took place in 1974, when, following the respective USSR resolution, ${ }^{49}$ people were allowed to register at the residence of their spouse, children or parents, regardless of the habitable area of space available at that address. This resolution certainly made the lives of some people easier.

\section{Shortcomings in the Soviet citizen registration process. Efforts to become a resident of the capital}

The control of the accuracy of the universal obligatory citizen registration process was one of the functions of the structures of the internal affairs system. It had to be carried out consistently. As it was announced in the press,

'The militsiya passport desk staff perform civil servant duties of great state importance. A great deal depends on the accuracy of their work and culture, and on their careful and undoubtedly correct record-keeping concerning the change and issue of passports, and citizen registration and de-registration.' 50

However, certain shortcomings did emerge during large-scale Soviet document checks and changes. In 1953, when the resolution for the exchange of temporary certificates for village residents was being implemented, it became evident that around 80,00o people had not been registered in the house books, most of them being

${ }^{48}$ A typical example of this story could have been as follows: in 1963 a woman asked the Vilnius city government for an apartment, as she had lived in the city as a sub-tenant since 1951, and during that time she had moved house several times, as her landlords had rented her a room until the first time they received a fine for violating the citizen registration rules. Then, each time she would have to search for a new place to live. G. J. declaration dated 11 June 1963 to the chairman of the Vilnius City Executive Committee's Apartments Commission, Vilnius Regional State Archives (VRVA), col. 761, inv. 9, file 925, pp. 41-41 lower.

49 USSR Council of Ministers Resolution No 678, 27 August 1974.

50 'Pasų stalų darbui - nuolatinį dèmesį', Milicijos darbuotojas, 5 July 1954, p. 1. 
children under the age of 16 (around 73,000$) \cdot{ }^{51}$ In addition, even though another 14,00o had been registered, they did not actually live at the specific address given. They had already moved to another place of residence. Similar cases existed in east and southeast Lithuania. We can see in general that living in the districts bordering the Belarusian SSR without any personal identity documents or registration documents was more common than in other regions of Lithuania. ${ }^{2}$ In this regard, the situation remained similar later on as well. In July 1976, when checking the accuracy of citizen registration records for the city of Šalčininkai, it was found that some people were renting out apartments or rooms to arrivals from Belarus, but that they had not been registered as such at the militsiya. The owners of these residences were ordered to register their tenants, and if this was impossible (as they were already registered in Belarus), they were ordered to move out. ${ }^{53}$ Similar cases existed in other districts bordering Belarus. ${ }^{54}$ A large number of unregistered citizens was also found in settlements on the outskirts of Vilnius (Nemėžis, Buivydiškės, Juodšiliai, Bezdonys, Riešè, etc). At the beginning of 1968, there were over 700 citizens who fell into this category. ${ }^{55}$ However, on the other hand, there were also some opposite cases, where some residents were simply 'on paper', i.e., they did not exist in reality. In 1966, the Vilnius region's Kairènai district board chairman received a fine for 'falsification

${ }^{51}$ Secret note of the LSSR Ministry of Internal Affairs Militsiya Board PassportRegistration Branch chairman Sergeyev, 26 June 1954, LYA, col. V-102, inv. 1, file 13, p. 26. There would also be exceptions where improperly handled documents could 'bury' a person. E. Straževičienè, 'Prisikèlusi iš numirusių', Liaudies sargyboje, 31 July 1965 , p. 4.

$5^{2}$ Secret note of the LSSR Ministry of Internal Affairs Militsiya Board PassportRegistration Branch chairman Sergeyev, 26 June 1954, LYA, col. V-102, inv. 1, file 13, p. 28.

53 Information about a check conducted on citizen registration in the city of Šalčininkai by staff from the State Statistical Inspectorate and the Ministry of Internal Affairs branch, 28 July 1976, VRVA, col. 1125, inv. l, file 264, p. 21.

${ }^{54}$ Explanation note from the Eišiškès District State Statistical Inspector A. Litvinov about the results of the one-off report on rural residents according to age and gender as of 1 January 1968, LCVA, col. R-363, inv. 1, file 10389, p. 107.

${ }_{55}$ Note from the Vilnius region state statistical inspector Bliumbergas about the results of the one-off report on rural residents according to age and gender in the Vilnius region as of 1 January 1968, ibid., file 10391, p. 218. 
of citizen registration documents. ${ }^{6}$ He had entered people on the district population lists who did not really exist. Population figures were manipulated in other regions of Lithuania as well, such as the Kèdainiai, Panevėžys, Šilalè, Ukmergè, Zarasai and other districts. ${ }^{57}$ Usually several hundred 'paper' citizens would appear. The practice whereby citizens existed only on paper guaranteed a higher salary or employment position for members of local government institutions.

There were cases where citizens could be registered at a location of their choice on the payment a fee. For example, in the Trakai district, several dozen people became residents on paying a specified sum to the member of staff conducting the registration. ${ }^{8}$

It should be noted that there was generally more improper conduct with the registration of citizens in rural areas. There were often cases where people who had left the district were still on the rural district population lists, while also being registered at their new place of residence. This error would become apparent when district house books were checked against population lists and passport desk data. For example, in 1963, based on district data, the mechanical population growth in towns due to the migration of the rural population was 28,200 , whereas according to passport desk calculations, this figure was $15,200 .{ }^{59}$ In practice, this meant that 13,000 people who had left rural areas had not been registered in towns. When the LSSR Central Board of Statistics checked the citizen registration records for 1964, it appeared that 3,800 people had been registered in Vilnius, even though they had not been de-registered from their previous place of residence. ${ }^{60}$ Similar checks were conducted at the time

${ }^{5}$ Protocol from the plenum of the CPL Vilnius District Committee, 30 March 1966, LYA, col. 3636 , inv. 37 , file 6, p. 57 .

${ }^{57}$ Results of the one-off report on rural residents according to age and gender as of 1 January 1968, LCVA, col. R-363, inv. 1, file 10389, pp. 77-78.

${ }^{8}$ Note from the LSSR Procurators' Office specially important case interrogator Babraitis, dated 15 November 1965 , to the LSSR Central Statistical Board chairman B. Dubasov, ibid., file 9o27, pp. 67-68.

${ }^{59}$ Mechanical population growth results for the LSSR in 1963 , ibid., file 6918, p. 8 .

${ }^{60}$ Statistical bulletin No 28. Natural Population Movement and Growth Indicators for 1965 , ibid., file 8323 , p. 39 . 
in 41 towns and 55 districts. ${ }^{61}$ The towns of Vilnius, Nemenčinè and Eišiškès and their districts were among the locations that were investigated. Subsequent obligatory citizen registration data checks showed that the situation was not improving. Staff from the LSSR Central Board of Statistics who checked data on mechanical growth in 1970-1978 showed that, at that time, 42,200 people from rural areas were registered in towns, who had not yet been de-registered from their previous place of residence. ${ }^{62}$

The most frequent violations to emerge were at enterprises and agencies where people were employed who were not registered at the location where the organisation operated, and when people under the age of 16 were not registered. The non-registration of this category must have been closely related to the first group, for children had to be registered according to their parents' passports. If the parents could not be registered at their new place of residence, the children also remained unregistered in the respective militsiya branches. The lives of some of the population without registration was a long-term phenomenon, which was never really solved during the Soviet period.

It is worth noting that the inaccurate registration of citizens was found to exist in Lithuania and other Soviet republics as well. For example, 7,649 people had de-registered, leaving Russian towns for Lithuania, but 7,949 people had registered in Lithuania, i.e., 300 people had arrived without having first de-registered from their previous place of residence. ${ }^{63}$ A similar situation existed in the case of arrivals from Ukraine and Latvia.

People were drawn to Lithuania from neighbouring republics on account of the professional and special secondary schools in Vilnius. This movement could be noticed in the first years after the war. However, when the number of applicants accepted into

${ }^{61}$ Results of the selected controlled check of departing citizens' registration and de-registration for June-July, 1964, ibid., file 7685, p. 41.

${ }^{62}$ Report on mechanical population movement in the republic by the LSSR Central Statistical Board's Population Statistics and Health Branch chairwoman M. Karalienè, ibid., file 18616, p. 21.

${ }^{63}$ Data about mechanical population movement in the LSSR in 1965, Ibid., col. R-363, inv. 1, file 8324 , p. 39 . 
institutions of higher and special secondary education that were concentrated in Vilnius could increase in the mid-196os, the number of young people in the city increased by around 3,000. ${ }^{64}$ It should be said that some of these institutions were especially appealing to Belarusian youths. In 1957, 34 people started the first-year course at the Naujoji Vilnia Pedagogical School, most of whom were originally from the neighbouring republic. ${ }^{65}$ There was also no shortage of young people from the BSSR at the Naujoji Vilnia Teachers' Institute, where $5^{\text {th }}$ to 7 th-grade teachers for Russian and Polish schools were trained, and also at the Vilnius Region School of Agricultural Mechanisation. As statistical data shows, over $5^{\circ}$ per cent of youths arriving in Vilnius from Belarus to study became students at vocational schools. ${ }^{66}$ However, there is no general data about the number of these youths in Lithuania, or specifically the Vilnius region. This situation is quite understandable. On one hand, studying and living in a large city was undoubtedly more desirable than working on a collective farm in Belarus. On the other hand, for young people from rural areas in the neighbouring republic, studying in Vilnius made it possible to receive a Soviet passport and feel like a freer citizen. Some Lithuanian vocational schools would accept youths aged 14 or 15 . On entering a school in Lithuania, when they turned 16, they would receive their first passport. Those who remained in Belarus would never have this opportunity, for until 1974, when amendments to the passport law came into effect, the residents of rural areas in the republic did not have any Soviet personal identification documents at all.

However, it should be noted that, even though Vilnius attracted citizens from all over Lithuania and other Soviet republics, it was still the place that had the most restrictions on registration. Readers are reminded that, like other capitals of Soviet republics, the city was included in the first category of 'passport regime areas'

${ }^{64}$ Report by the Vilnius Statistical Board chairman about mechanical population movement in Vilnius, 4 April 1966, ibid., file 8324, p. 27.

${ }^{65}$ Meeting protocol of the Naujoji Vilnia Pedagogical School's Teachers Board, 17 September 1957, VRVA, col. 1151, inv. 1, file 31, p. 10.

${ }^{66}$ В. Станкунене, 'Факторы и источники численности Вильнюса', in: Размещение промышленности и развитие городов в Литовской ССР (Вильнюс, 1979), p. 133 . 
from 1944. In reality, this meant that certain individuals (who were viewed as unreliable in the eyes of the Soviet government, or who had been convicted of political or criminal crimes, etc) could not be registered or live in the city. On the other hand, the 'sanitary norms' that existed in cities also severely restricted opportunities for citizens to become city dwellers. The essence of this rule was as follows: in order to register as living in an apartment, one person had to have an area of at least nine square metres (or 4.5 square metres in a communal apartment). ${ }^{67}$ Since there was a serious shortage of habitable space in Vilnius, being registered in the city was not at all easy. In addition, the supreme government of the USSR enforced stricter registration procedures in Moscow, Leningrad and the capitals of union republics during the years of political liberalisation. ${ }^{68}$ The leaders of separate republics and cities followed this example (in Riga and Vilnius). In the middle of 1957, the republic's leaders passed a resolution on citizen registration and the allocation of living space in Vilnius. The city leadership complained that there was a severe shortage of living space in Vilnius, due to the influx of people wanting to live there, even leading to an oversupply of labour. ${ }^{69}$ However, the leaders of separate city enterprises and agencies ignored the opinions

${ }^{67}$ In Vilnius, at specific times, decisions were made to increase the population density, whereupon a norm of seven square metres for each city-dweller had to apply. This situation existed in 1944-1945, when government institutions and their staff were transferred from Kaunas to the LSSR capital, and there was still a major shortage of living space in Vilnius due to damage caused during the war. Another particularly dense area in Vilnius was the former Roma tabor (settlement) in the Soviet suburb (it covered the southern part of the city). At the end of 1985, there were 163 people living in an area of 123.4 square metres. Report to the LSSR Ministry of Internal Affairs on the check of the Vilnius Soviet suburb by the Ministry of Internal Affairs branch, 3 December 1985, LYA, col. V-105, inv. 1, file 81, p. 204. For comparison, in Tallinn, the capital of Estonia, a 'sanitary norm' of 12 square metres per person applied, I. Paavle, 'The Evolution, Regulation and Implementation..., Part I, p. 11.

${ }^{68}$ Resolution No $1578-796$ of the USSR Council of Ministers, 10 December 1956, LCVA, col. R-754, inv. 14, file 79, p. 265 .

${ }^{69}$ Report by the secretary of the Vilnius City Communist Party M. Kenevich and the executive committee chairman J. Vildžiūnas, dated 24 November 1957, to the secretary of the CPL CC A. Sniečkus and the chairman of the LSSR Council of Ministers M. Šumauskas, ibid., inv. 4, file 416o, p. 146. 
of the city administration, and would employ people who were not from Vilnius. The leaders of these enterprises would usually demand their new employees be allocated a place to live. This only served to worsen the situation. As a result, the resolution mentioned foresaw restrictions on the growth of the city's population, i.e., to further restrict citizen registration. However, the city's administrative government, which until had then struggled, though to no avail, against agencies and organisations that transferred staff or directed new employees to the capital, ${ }^{\circ}$ began to limit citizen registration altogether. This was not so difficult, for a resolution dated 21 August 1957 transferred the control of citizen registration to the hands of the city's Executive Committee. ${ }^{71}$ The latter limited the issue of documents required for registration, and also started using new house books, thereby implementing the re-registration of city dwellers. ${ }^{72}$ The results of this practice soon became apparent. By 1957, compared to the previous year, there were already 2,800 fewer people on the records, while an additional 4,700 people had been de-registered from the city. ${ }^{73}$ In addition, intensive checks were under way on how stringently the passport regime rules were being adhered to, i.e., whether a person had re-registered, and if so, on what grounds, and whether they had valid personal identity documents. Quite a few violators of the Soviet order were uncovered. For example, 24 people were

${ }^{70}$ For example, of the 13,400 adults who arrived in Vilnius in $195^{8}, 305$ had been sent to work in the city, while 307 were young specialists appointed to the capital. Note about the registration and the de-registration of citizens in Vilnius in 1958 , ibid., inv. 4 , file 4823 , p. 2.

${ }^{71}$ Report by the secretary of the Vilnius City Communist Party M. Kenevich and the Executive Committee chairman J. Vildžiūnas dated 24 November 1957 to the secretary of the CPL CC A. Sniečkus and the chairman of the LSSR Council of Ministers M. Šumauskas, ibid., file 416o, p. 146; resolution of the Vilnius City Communist Party and Executive Committee dated 21 August 1957, ibid., p. 153.

${ }^{72}$ Report by the secretary of the Vilnius City Communist Party M. Kenevich and the Executive Committee chairman J. Vildžiūnas dated 24 November 1957 to the secretary of the CPL CC A. Sniečkus and the chairman of the LSSR Council of Ministers M. Šumauskas, ibid., p. 148.

${ }^{73}$ Report by the secretary of the Vilnius City Communist Party M. Kenevich and the Executive Committee chairman J. Vildžiūnas dated 24 November 1957 to the secretary of the CPL CC A. Sniečkus and the chairman of the LSSR Council of Ministers M. Šumauskas, Ibid., col. R-754, inv. 4, file 416o, p. 147. 
convicted of multiple passport regime violations, 2,419 were ordered to leave the city, and 3,002 people were fined. ${ }^{74} \mathrm{~A}$ similar situation existed later as well.

However, the possible fines did not dissuade people from wanting to become residents of Vilnius. Various ways of getting around the rules were explored. One way of becoming a resident of the capital was to live in the city unregistered, renting a room, or part of one. This method was rather widespread, but it was far from convenient, as the owner was constantly under threat of receiving a fine. For example, in 1983, around 300 apartment owners were fined over a period of eight months in the Spalis suburb of Vilnius for 'keeping tenants. ${ }^{75}$ These kinds of violations were uncovered both in earlier and later years. An administrative violation such as this attracted a fine of up to 30 roubles. ${ }^{76}$ Another way was not to have a permanent place of residence in the city. There was no shortage of people without a fixed abode (vagrants) in Vilnius who had arrived at various times from cities in Russia, Ukraine and Belarus (Smolensk, Tula, Minsk, Gomel, Kiev, Smarhon', etc). ${ }^{77}$ The situation had not even changed much in this regard several decades later: Vilnius continued to attract these kinds of people from other republics.

In the second half of the 1970s, once the registration process had been somewhat liberalised, more Lithuanians started being registered in Vilnius with the approval of the local city authorities. As Algirdas Vileikis, the long-serving chairman of the city's Executive Committee, recalled, 'On becoming chairman, I passed an unwritten provision to ensure that no less than $5^{\circ}$ per cent of those living in Vilnius were Lithuanian. No norms for registration in Vilnius would apply to Lithuanians who lived in Lithuania. If

74 Ibid., p. 148.

${ }^{75}$ Secret note from the LSSR Ministry of Internal Affairs Passports Branch senior inspector M. Savichenko about the check of the Vilnius Spalis suburb by a branch of the Ministry of Internal Affairs, 15-19 August 1983, LYA, col. V-105, inv. 1, file 81, p. 65.

${ }^{76}$ Normatyviniu aktu rinkinys milicijos darbuotojai, p. 119.

${ }^{77}$ Note from the Vilnius City Executive Committee Social Welfare Branch chairman Dambrauskas, dated 13 February 1953, to the LSSR minister of social welfare, VRVA, col. 761, inv. 9, file 450, p. 26. 
a street pole had a residential address, a [suitable] person could be registered there, if a shed had an address, one could register there as well. ${ }^{78}$ This approach by the city authorities contributed to changes to the ethnic composition of the city's inhabitants. Nonetheless, it is worth noting that other reasons (the intensive development of the industrial sector, agricultural reforms, the development of Lithuanian culture and science, etc) had a greater impact on the concentration of Lithuanians in the city. Statistical data shows that in 1979-1989, the number of Lithuanians increased by 66,400 (from 225,100 to 291,500 ), and other nationalities by 34,500 (from 250,700 to 285,200 ). ${ }^{79}$ If we compare it with the period 1951 to 1957 , the difference is as follows: the number of Lithuanians increased by 17,900 (from 45,300 to 63,300 ), and Russians, Poles, Belarusians, Ukrainians and other nationalities by 23,400 (from 134,000 to 157,400 ). ${ }^{80}$ The result of this process was that by the end of the Soviet period, every other resident of Vilnius was Lithuanian.

\section{Conclusions}

Several stages can be distinguished in the development of the Soviet passport system in Lithuania: 1) the period 1944 to 1953 was noted for the restoration of the passport system, with the aim of employing it for the accelerated Sovietisation of Lithuania. Therefore, in accordance with the resolution of the leaders of the USSR, every citizen of the republic older than 16 had to receive a document certifying their Soviet identity, and to be registered at their place of residence. These measures made the control of society and the search for and isolation of people opposed to the

${ }^{78}$ I. Liutkevičienè, Déjà vu, p. 43.

${ }^{79}$ V. Stankūnienè, 'Demographic Development of Vilnius in the Historical Context', in: Lietuvos demografiniai pokyčiai ir gyventoju politika, ats. red. V. Stankūnienè, (Vilnius 1995), p. 38.

${ }^{80}$ V. Stravinskiene, 'Migracijos procesu poveikis..., p. 149; Report by the secretary of the Vilnius City Communist Party M. Kenevich and the Executive Committee chairman J. Vildžiūnas, dated 24 November 1957, to the secretary of the CPL CC A. Sniečkus and the chairman of the LSSR Council of Ministers M. Šumauskas, LCVA, col. R-754, inv. 4, file 416o, p. 147. 
government extremely simple, and restricted the free movement of the population; 2) the period 1953 to 1989 can be viewed as a period of modernisation of the Soviet passport system, related to political, economic and social change. Millions of persecuted individuals were released from Soviet labour camps, and enormous industrial and agricultural development projects were launched, which determined increased migration processes, whose regulation was made easier by the liberalised citizen registration and passport system).

Due to the Soviet government's homogenisation plan implemented in the western territories of the state (1944-1946), a unique situation developed in east and southeast Lithuania. The Polish population in this part of the country were viewed as citizens of Poland, who had to move to the new geographic space that had become available in Poland. The issue of passports to the population in Vilnius was used to force through the resettlement campaign.

The LSSR party administrative government used the mandatory citizen registration system in order to control people's lives, and to make decisions regarding economic and social issues in the republic. The preferred place to live in the republic was Vilnius, the capital, which attracted people from other parts of Lithuania, and from other Soviet and autonomous republics. As a result, the city's growth was too fast. In order to halt this demographic growth, the republic and city governments passed resolutions that restricted the registration of certain population groups in the city, while simplifying conditions for others (Lithuanians) to settle there. As a result, the ethnic structure of the population gradually changed, and the number of Lithuanians increased.

\section{Author Details}

Vitalija Stravinskienè is a research fellow in the Department of 2oth-Century History at the Lithuanian Institute of History. Her area of research is Vilnius and east and southeast Lithuania in the 2oth century.

Address: Lithuanian Institute of History, 5 Kražių St, Vilnius LT-o11o8, Lithuania E-mail: vitalija.stravinskiene@istorija.lt 


\section{Bibliography}

JAKINEVIČIŪTĖ, I. Pasu įteikimo vakaras - jaunuju piliečiu šventé (Vilnius, 1964).

KAIRIŪKŠTYTĖ, Nastgazija. 'Vilniaus krašto gyventojų sudėties pokyčiai 1939-1946 m.', in: Lietuvos Rytai, sud. K. Garšva, L. Grumadienė (Vilnius, 1993), pp. 281-298.

KESSLER, Gijs. 'The Pasport System and State Control over Population Flows in the Soviet Union, 1932-1940', Cahiers du monde russe, vol. 42 (2001), pp. 477-504.

KIRICHENKO, Yulia. 'Historic and Legal Review on Passport Reform of 1974 and its Role in Strengthening of the USSR Public Order', Bylye Gody, 2014, № 34 (2014), pp. 707-713.

KUNIGĖLYTĖ-ŽIŪKIENĖ, Birutè. Valstybiu teisiu perèmimas, neteisèti teritoriniai pokyčiai ir pilietybė. Doctoral dissertation (Vilnius, 2015).

LAUKAITYTĖ, Regina. 'Sovietinio pasų režimo įvedimas Lietuvos SSR 1944-1953 metais', Teisé, t. 107 (2018), pp. 51-65.

LIUTKEVIČIENE, Inga. Deja vu. Vilnius 1974-199o (Vilnius, 2012).

MATTHEWS, Mervyn. Passports and Residence Controls in the Soviet Union (1991).

RÖMER, Michal. Dzienniki, t. 6: 1939-1945, oprac. J. Sienkiewicz (Warszawa, 2018).

PAAVLE, Indrek. 'The Evolution, Regulation and Implementation on the Soviet Internal Passport System in the Estonian SSR, Part I', Tuna, Nr. 2 (2010), pp. 37-53.

PAAVLE, Indrek. 'The Evolution, Regulation and Implementation on the Soviet Internal Passport System in the Estonian SSR, Part II', Tuna, Nr. 2 (2011), pp. 43-67.

'Pasų stalų darbui - nuolatinį dèmesį, Milicijos darbuotojas, 5 July 1954, p. 1.

SAFRONOVAS, Vasilijus. Migrantai ir pabėgèliai Kuršiu nerijoje XX amžiaus viduryje (Vilnius, 2018).

SINKEVIČIUS, Vytautas. Lietuvos Respublikos pilietybe 1918-2001 metais (Vilnius, 2002).

STANKŪNIENE, Vlada. 'Demographic Development of Vilnius in the Historical Context', in: Lietuvos demografiniai pokyčiai ir gyventoju politika, ats. red. V. Stankūnienė (Vilnius, 1995), pp. 21-41.

STRAVINSKIENE, Vitalija. 'Migracijos procesų poveikis Vilniaus miesto gyventojų etniniams demografiniams pokyčiams 1944-1959 metais', Lietuvos istorijos metraštis 2009/2, pp. 133-152. 
STRAVINSKIENĖ, Vitalija. Tarp gimtinès ir Tëvynès: Lietuvos SSR gyventoju repatriacija i Lenkija (1944-1947, 1955-1959 m.) (Vilnius, 2011).

STRAŽEVIČIENĖ, E. 'Prisikèlusi iš numirusių', Liaudies sargyboje, 31 July 1965, p. 4.

БАЙБУРИН, Альберт. 'К предысловии советского паспорта (1917-1932), in: Непрекосновенный запас, 2(64) (2009).

БАЙБУРИН, Альберт. Советский паспорт. История-структура-практики (Санкт-Петербург, 2017).

ГУРА, Галина. 'Особенности паспортной системы Российской Федерации', Територия науки, 2013, №5 5 , (2013), р. 163.

ЛЮБАРСКИЙ, Кронид. 'Паспортная система и система прописки в СССР', in: Российский бюллетень по правам человека, vol. 2 (1994), pp. 14-24.

МУАН Натали. 'Паспортная система и выбор места жительства в Росии и Советском Союзе', Непрекосновенный запас, 4(42) (2005).

ПОПОВ, Василий. 'Паспортная система советского крепосничества ', Новый мир, № 6, (1996).

Режимные люди в СССР, отв. ред. Т. С. Кондратьева, А. К. Соколов (Москва, 2009)

СТАНКУНЕНЕ, Влада. 'Факторы и источники численности Вильнюса', in: Размещение промышленности и развитие городов в Литовской ССР (Вильнюс, 1979), pр. 101-178.

CHERNOLUDSKAYA, Elena. 'Паспортизация Дальневосточного населения (1933-1934)', Revue des Études Slaves', t. 71, fas. 1 (1999), pp. 17-33. 


\title{
SOVIETINĖ PASPORTIZACIJA IR JOS İGYVENDINIMAS: RYTŲ IR PIETRYČIŲ LIETUVOS ATVEJIS (1944-1989 M.)
}

\author{
Santrauka
}

\section{VITALIJA STRAVINSKIENE}

Sovietinė valdžia stengėsi vykdyti totalitarinę individo gyvenimo kontrolę. Turbūt efektyviausias būdas kontroliuoti asmenį buvo nedidelio formato knygelè - sovietinis pasas, be kurio žmogus negalèjo nei įsidarbinti, mokytis, kurti šeimos, pakeisti gyvenamosios vietos. Straipsnyje, remiantis archyvine ir istoriografine medžiaga, nagrinëjamas sovietinės pasų sistemos įdiegimas Lietuvoje 1944-1989 m., dėmesi sutelkiant į Rytų ir Pietryčių Lietuvą. Aiškinamasi, kaip buvo diegiama ir tobulinama sovietinė pasų sistema, kokią reikšmę turẻjo privaloma visuotinė gyventojų registracija, kaip ji funkcionavo.

LSSR sovietinės pasų sistemos raidoje išskirtini keli etapai: 1) 1944-1953 m. - pasų sistemos atkūrimas turint tikslą ją pasitelkti spartesnei Lietuvos sovietizacijai. Todèl visi vyresni negu 16 metų amžiaus respublikos gyventojai privalèjo gauti sovietini tapatybę patvirtinantį dokumentą ir būti įregistruoti pagal gyvenamają vietą. Šios priemonės labai palengvino visuomenès kontrolę, valdžiai priešiškai nusiteikusių asmenų paiešką ir izoliavimą, varžė gyventojų laisvą judẻjimą; 2) 1953-1989 m. sovietinès pasų sistemos modernizavimas, susijęs su politiniais, ekonominiais ir socialiniais pokyčiais (iš sovietinių lagerių buvo paleista milijonai represuotų gyventojų, igyvendinami gigantiški pramonès ir žemès ūkio plètros projektai lèmè išaugusius migracinius procesus, kuriuos reguliuoti padejjo liberalizuota gyventojų registracijos ir pasų sistema).

Dèl sovietinès valdžios vykdyto vakarinių valstybės teritorijų homogenizavimo plano (1944-1946 m.) Rytų ir Pietryčių Lietuvoje susidarė išskirtinė padėtis. Šio regiono gyventojai lenkai buvo vertinami kaip Lenkijos piliečiai, kurie turejo persikelti į naujoje geografinèje erdvejje atsidūrusią Lenkiją. Tuo metu vykdyta gyventojų pasportizacija Vilniuje buvo panaudota perkèlimo akcijai forsuoti.

LSSR partinè administracinè valdžia naudojosi veikusia privalomos gyventojų registracijos sistema norėdama kontroliuoti piliečių gyvenimą, spręsdama respublikos ūkinius ar socialinius klausimus. Patraukliausia vieta gyventi buvo respublikos sostinė Vilnius, kuris traukė ne tik kitų lietuviškų regionų, bet ir kitų sovietinių ar autonominių respubliku gyventojus. Todèl miestas augo hipertrofuotai. Siekdama pristabdyti tokị Vilniaus demografini augimą, respublikos ir miesto valdžia savo sprendimais ribojo tam tikrų gyventojų grupių registraciją mieste, o kitiems (lietuviams) lengvino sąlygas ịsikurti. Dèl to mieste pamažu kito etninė gyventojų sudètis ir išaugo lietuvių skaičius. 